\title{
PENGARUH KADAR KAPUR TERHADAP KUAT GESER DAN PERMEABILITAS TANAH BERBUTIR KASAR
}

\author{
Arman Setiawan \\ Jurusan Teknik Sipil, FakultasTeknik, Universitas Bosowa \\ Email: arman_c97@yahoo.com
}

\begin{abstract}
ABSTRAK
Pasir tanah dalam kondisi padat cenderung memiliki sifat yang baik. Namun dalam kondisi tertentu, seperti saat dalam kondisi longgar dan jenuh air, mungkin memiliki kekuatan geser rendah bila ada beban siklik seperti gempa bumi. Dalam keadaan ini lapisan pasir kehilangan kekuatan gesernya atau menurun. Secara umum, kekuatan geser tanah pasir disumbangkan oleh nilai sudut gesek internal. Untuk meningkatkan kekuatan geser, perbaikan tanah sering dilakukan dengan inklusi serat atau campuran semen. Penelitian ini bertujuan untuk menguji perubahan kekuatan geser dan permeabilitas antara butir kasar (granular) ditambah dengan kapur. Penelitian ini menggunakan eksperimen yaitu dengan eksperimen untuk mendapatkan hasil, dengan pengaruh kapur pada konstruksi jalan raya atau bangunan. Hasil penelitian menunjukkan bahwa rasio tegangan geser maksimum terjadi pada persentase campuran $12 \%$ yaitu $c=0,1313 \mathrm{~kg} / \mathrm{cm} 2$ dan $\phi=11,537^{\circ}$ dibandingkan dengan tanah asli yaitu $c=0,016 \mathrm{~kg} / \mathrm{cm} 2$ dan $\phi=27,607^{\circ}$. Pada pengujian Permeabilitas kenaikan maksimum terjadi pada campuran $12 \%$ yaitu $\mathrm{k}$ $=0,00243 \mathrm{~cm} /$ detik dibandingkan dengan tanah asli yaitu $\mathrm{k}=0,00826 \mathrm{~cm} /$ detik.
\end{abstract}

Kata Kunci: Tanah Pasir, Kapur, Kekuatan Geser, Permeabilitas

\section{PENDAHULUAN}

Tanah pasir dalam kondisi padat cenderung memiliki sifat-sifat yang baik. Namun pada kondisi tertentu, seperti bila dalam kondisi lepas dan jenuh air, dapat memiliki kuat geser yang rendah ketika terjadi beban siklik seperti gempa bumi. Pada keadaan ini lapisan pasir kehilangan kuat gesernya atau berkurang.

Secara umum, kuat geser tanah pasir disumbangkan oleh nilai sudut gesek internal. Guna meningkatkan kuat gesernya, perbaikan tanah pasir sering dilakukan dengan inklusi serat atau campuran semen. Kapur dan abu sekam padi sebagai bahan stabilisasi tanah lempung sudah banyak diteliti, namun penggunaannya untuk tanah pasir belum banyak dikaji. Untuk itu dalam penelitian ini akan dikaji pengaruh campuran kapur dan abu sekam padi terhadap kuat geser tanah pasir.

Pada kebanyakan penelitian, teknik perbaikan tanah yang sering digunakan adalah teknik stone-column atau stone-piers. Teknik ini mampu mengurangi resiko kerusakan struktur akibat peristiwa likuifaksi. Namun demikian teknik perbaikan tanah lainnya seperti teknik kolom dengan bahan kapur atau semen dapat digunakan sebagai alternatif untuk mengurangi resik likuifaksi. Selain itu, teknik kolom ini juga dapat digunakan sebagai fondasi untuk bangunan gedung. Dalam perkembangannya, bahan untuk kolom dapat berupa colloidal-silica yaitu silika dalam bentuk gel atau cair. Pada sisi lain, abu sekam padi yang banyak mengandung pozzolan 
silika (SiO2) padat yang berukuran mikro merupakan bahan yang sangat baik jika dicampur dengan kapur. Hasil reaksi kapur-abu sekamp padi akan membentuk bahan penyusun semen. Untuk itu penggunaannya dengan kapur untuk mitigasi likuidasi adalah suatu alternatif pemanfaatan bahan.

Maksud dari penelitian ini adalah untuk menguji perubahan kuat geser dan permeabilitas antara tanah berbutir kasar (granuler) yang di tambah dengan kapur. Sedangkan Tujuan dari penelitian ini adalah untuk mengetahui besarnya pengaruh penambahan kapur pada tanah berbutir kasar (granuler) terhadap kuat geser dan permeabilitas.

\section{KAJIAN PUSTAKA}

\subsection{Struktur Tanah}

Struktur tanah merupakan sifat fisik tanah yang menggambarkan susunan keruangan partikel-partikel tanah yang bergabung satu dengan yang lain membentuk agregat. Dalam tinjauan morfologi, struktur tanah diartikan sebagai susunan partikel-partikel primer menjadi satu kelompok partikel (cluster) yang disebut agregat, yang dapat dipisah-pisahkan kembali serta mempunyai sifat yang bebeda dari sekumpulan partikel primer yang tidak teragregasi. Dalam tinjauan edafologi, sejumlah faktor yang berkaitan dengan struktur tanah jauh lebih penting dari sekedar bentuk dan ukuran agregat. Dalam hubungan tanah-tanaman, agihan ukuran pori, stabilitas agregat, kemampuan teragregasi kembali saat kering, dan kekerasan (hardness) agregat jauh lebih penting dari ukuran dan bentuk agregat itu sendiri. Struktur tanah berpengaruh terhadap gerakan air, gerakan udara, suhu tanah, dan hambatan mekanik perkecambahan biji serta penetrasi akar tanaman. Karena kompleksnya peran struktur, maka pengukuran struktur tanah didekati dengan sejumlah parameter. Beberapa parameter tersebut antara lain bentuk dan ukuran agregat, agihan ukuran agregat, stabilitas agregat, persentase agregat, porositas (BV, BJ), agihan ukuran pori, dan kemampuan menahan air.

2.2. Klasifikasi Tanah

\subsubsection{Ukuran Butiran dan Gradasi}

Ukuran butiran dan gradasi sangat penting bagi sifat - sifat mekanis dari sebuah tanah. Definisi berarti ini, dengan referensi terhadap ukuran butiran, digunakan :

\begin{tabular}{|l|l|}
\hline $\begin{array}{l}\text { Blok ( batu guling ) } \\
\text { Batu ( Kerakal ) } \\
\text { Kerikil }\end{array}$ & $\begin{array}{l}\text { Partikel - pertikel berbutir kasar yang dapat diidentifikasi dengan } \\
\text { pemeriksaan okuler dan lebih teliti dengan analisis saringan }\end{array}$ \\
\hline $\begin{array}{l}\text { Lumpur } \\
\text { Tanah Liat }\end{array}$ & $\begin{array}{l}\text { Partikel - partikel berbutir halus. Partikel - partikel tak dapat } \\
\text { dilihat dengan secara visual sendiri - sendiri. } \\
\text { Diidentifikasi dan diklasifikasi dengan analisis hydrometer dan uji } \\
\text { - uji khusus lainnya. }\end{array}$ \\
\hline
\end{tabular}


Tanah yang digradasi secara seragam dengan partikel - partikel kurang lebih sama ukurannya, mempunyai sebuah koefisien uniformitas ( keseragaman ) :

$C_{u}=\frac{D_{60}}{D_{10}}$ kurang dari $\sim 5$

Dimana $D_{60}$ dan $D_{10}$ adalah diameter partikel yang sesuai dengan nilai 60 dan 10 persen pada kurve gradasi. Tanah yang digradasi baik, mempunyai sebuah koefisien uniformitas ( keseragaman ) $C_{u}$ lebih besar dari pada $\sim 5$. Dalam hal ini rongga di antara partikel - partikel yang lebih besar diisi dengan partikel - partikel yang lebih kecil dan tanah yang digradasi baik membuat sebuah urukan yang lebih stabil daripada tanah yang digradasi uniform.

\subsection{Stabilisasi Tanah}

\subsubsection{Stabilisasi Tanah Berbutir Kasar Dengan Kapur ( Lime Stabilization)}

Dengan penambahan kapur akan mereduksi plastisitas tanah, meningkatkan kekuatan dan daya tahan, meningkatkan penyerapan air dan pengembangan (swelling) yang diakibatkan oleh air. Pada keadaan ini efek stabilisasi adalah karena proses kimia tertentu dan bukanlah suatu penguatan akibat perlakuan mekanis. Proses kimia ini mengubah struktur tanah dengan cara pembentukan agregat butir yang lebih besar (flokulasi), dan hal inilah yang sangat menguntungkan untuk suatu konstruksi. Penambahan kapur mempengaruhi karakteristik pemadatan, yaitu kadar air optimum (wopt) naik, berat volume kering maksimum ( $\gamma d m a k s)$ turun dan kurva pemadatan lebih datar.

Peningkatan kekuatan (strength) akibat dari stabilisasi berbutir kasar dengan kapur disebabkan 3 reaksi yang terjadi, yaitu: penyerapan air (hydration of soin, flocculation/pertukaran ion (ion exchange), dan cementation (pengerasan)/reaksi pozolan (pozzolanic reaction). Mekanisme lainnya adalah karbonisasi (carbonation), reaksi ini menyebabkan sedikit peningkatan kekuatan, sehingga dapat diabaikan. Reaksi cepat (short term reaction) meliputi hidrasi untuk kapur hidup dan flokulasi. Reaksi lambat (long term reaction) meliputi sementasi (cementation) dan karbonisasi (carbonation).

\subsection{Analisa Sifat Mekanis Tanah}

\subsubsection{Permeabilitas Tanah}

Permeabilitas adalah kemampuan bahan yang berpori untuk melewatkan aliran (rembesan) dari fluida (air / minyak) melalui rongga pori - porinya. Jamulya dan Suratman Woro Suprodjo (1983), mengemukakan bahwa permeabilitas adalah cepat lambatnya air merembes ke dalam tanah baik melalui pori makro maupun pori mikro baik ke arah horizontal maupun vertikal. Tanah adalah kumpulan partikel padat dengan rongga yang saling berhubungan. Rongga ini memungkinkan air dapat mengalir di dalam partikel melalui rongga dari satu titik yang lebih tinggi ke titik yang lebih rendah. Sifat tanah yang memungkinkan air melewatinya pada berbagai laju alir tertentu disebut permeabilitas tanah. Sifat ini berasal dari sifat alami granuler tanah, meskipun dapat dipengaruhi oleh faktor lain (seperti air terikat di tanah liat). Jadi, tanah yang berbeda akan memiliki permeabilitas yang berbeda. 


\subsubsection{Kuat Geser Tanah}

Parameter kuat geser tanah diperlukan untuk analisis - analisis kapasitas dukung tanah, stabilitas lereng, dan gaya dorong pada dinding penahan tanah. Menurut teori Mohr (1910) kondisi keruntuhan suatu bahan terjadi oleh karena akibat adanya kombinasi keadaan kritis dari tegangan normal dan tegangan geser. Hubungan fungsi antara tegangan normal dan tegangan geser pada bidang rumahnya, dinyatakan oleh persamaa:

$\tau=\boldsymbol{f}(\boldsymbol{\sigma})$

Dengan $\tau$ adalah tegangan geser pada saat terjadinya keruntuhan atau kegagalan (failure), dan $\sigma$ adalah tegangan normal pada saat kondisi tersebut. Kuat geser tanah adalah gaya perlawanan yang dilakukan oleh butir - butir tanah terhadap desakan atau tarikan. Dengan dasar pengertian ini, bila tanah mengalami pembebanan akan ditahan oleh:

1) Kohesi tanah yang bergantung pada jenis tanah dan kepadatannya, tetapi tidak tergantung dari tegangan normal yang bekerja pada bidang geser.

2) Gesekan antara butiran - butiran tanah yang besarnya berbanding lurus dengan tegangan normal pada bidang gesernya.

Coulomb ( 1776 ) mendefenisikan $f(\sigma)$ sebagai :

$\tau=c+\sigma \operatorname{tg} \varphi$ 
3. METODE PENELITIAN

3.1. Diagram Alur Penelitian

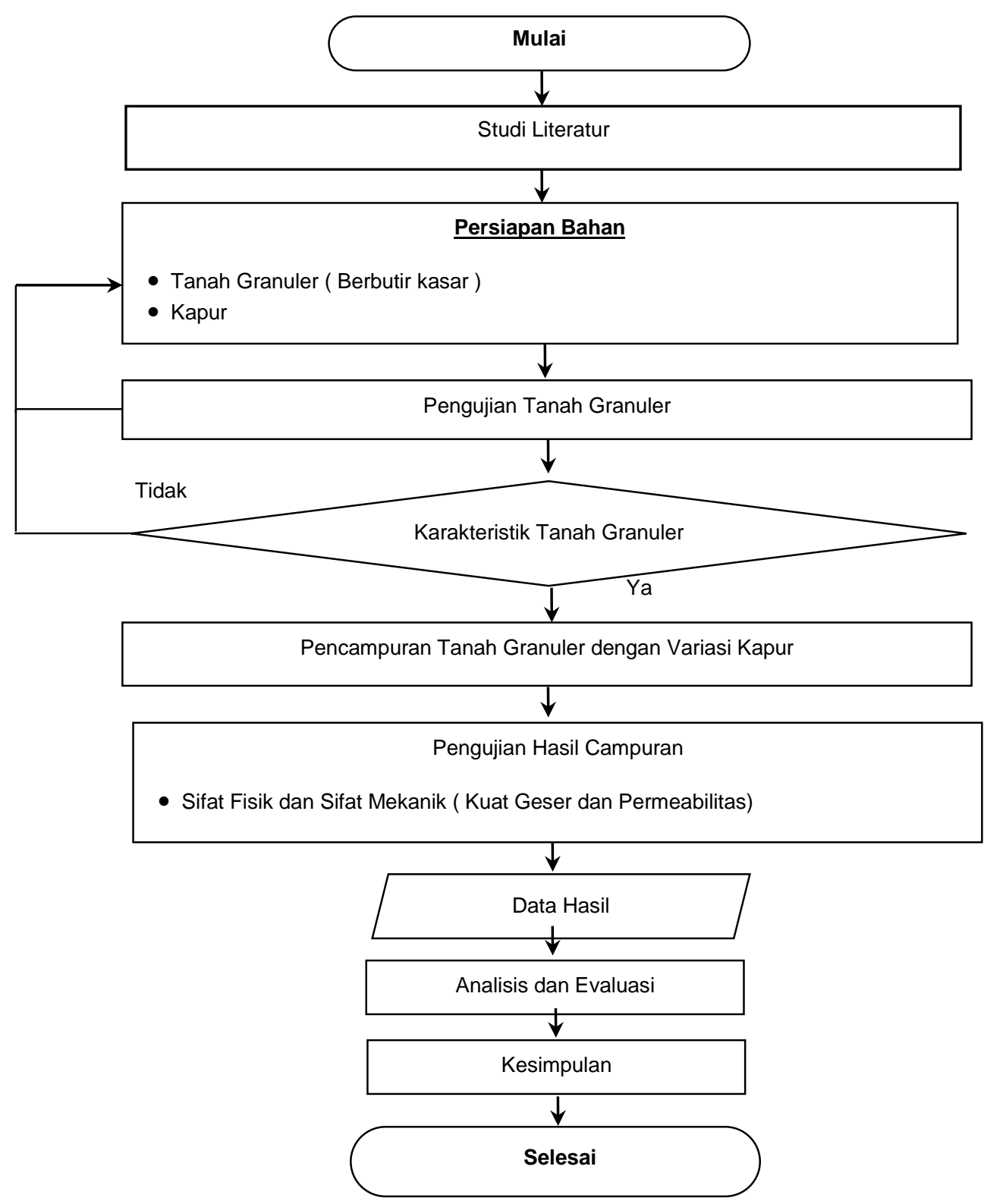

Gambar 1. Bagan Alir Penelitian

3.2. Variabel Penelitian

1. Variabel bebas yaitu kadar kapur

2. Variabel terikat yaitu kuat geser dan permeabilitas tanah berbutir kasar. 


\subsection{Notasi Sampel}

Tabel 1 Notasi Sampel dalam setiap pengujian

\begin{tabular}{|c|c|c|c|c|c|c|}
\hline \multirow{2}{*}{ No } & \multirow{2}{*}{ Jenis Percobaan } & \multirow{2}{*}{ Komposisi Campuran } & \multicolumn{3}{|c|}{ Berat Material } & \multirow{2}{*}{$\begin{array}{c}\text { Berat } \\
\text { Campuran (gr) } \\
\end{array}$} \\
\hline & & & Tanah ( gr) & Kapur ( gr) & Air ( $\mathrm{ml})$ & \\
\hline \multirow{7}{*}{1} & \multirow{7}{*}{$\begin{array}{l}\text { Kompaksi } \\
\text { ( Standar Proktor Test ) }\end{array}$} & Tanah Asli & 10000 & 0 & & 10000 \\
\hline & & & & & & \\
\hline & & Tanah + 4\% Kapur & 10000 & 416,67 & & 10416,67 \\
\hline & & Tanah + 6\% Kapur & 10000 & 638,30 & & 10638,30 \\
\hline & & Tanah + 8\% Kapur & 10000 & 869,57 & & 10869,57 \\
\hline & & Tanah + 10\% Kapur & 10000 & 1111,11 & & 11111,11 \\
\hline & & Tanah + 12\% Kapur & 10000 & 1363,64 & & 11363,64 \\
\hline \multirow{6}{*}{2} & \multirow{6}{*}{$\begin{array}{l}\text { Geser Langsung } \\
\text { ( Direact Shear ) }\end{array}$} & Tanah Asli & 450 & 0 & & 450 \\
\hline & & Tanah + 4\% Kapur & 450 & 1875 & & 46875 \\
\hline & & Tanah + 6\% Kapur & 450 & $\frac{10,15}{28,72}$ & & $\frac{400, r 3}{478,72}$ \\
\hline & & Tanah + 8\% Kapur & 450 & 39,13 & & 489,13 \\
\hline & & Tanah + 10\% Kapur & 450 & 50,00 & & 500,00 \\
\hline & & Tanah + 12\% Kapur & 450 & 61,36 & & 511,36 \\
\hline \multirow{7}{*}{3} & \multirow{7}{*}{$\begin{array}{l}\text { Rembesan } \\
\text { ( Permeabilitas ) }\end{array}$} & Tanah Asli & 1000 & 0 & & 1000 \\
\hline & & & & & & $1011 \cap 7$ \\
\hline & & Tanah + 4\% Kapur & 1000 & 41,67 & & $1041,6 /$ \\
\hline & & Tanah + 6\% Kapur & 1000 & 63,83 & & 1063,83 \\
\hline & & Tanah + 8\% Kapur & 1000 & 86,96 & & 1086,96 \\
\hline & & Tanah $+10 \%$ Kapur & 1000 & 111,11 & & 1111,11 \\
\hline & & Tanah + 12\% Kapur & 1000 & 136,36 & & 1136,36 \\
\hline & & & 57250 & 5037,17 & & 73737,17243 \\
\hline
\end{tabular}

4. HASIL DAN PEMBAHASAN

4.1. Hasil Pengujian

4.1.1. Hasil Pemeriksaan Karakteristik Tanah

Tabel 2 Hasil Pengujian Sifat Fisik Tanah

\begin{tabular}{|c|c|c|c|c|}
\hline No & \multicolumn{2}{|c|}{ Pengujian } & Hasil Uji & Satuan \\
\hline \hline 1. & \multicolumn{2}{|l|}{ Berat Jenis } & 2,66 & \\
\hline 2. & Analisa Saringan & & \\
\hline & No. Saringan & $\begin{array}{c}\text { Ukuran Partikel } \\
(\mathrm{mm})\end{array}$ & & \\
\hline & 4 & 4,750 & 100 & $\%$ \\
\hline & 40 & 0,425 & 99.98 & $\%$ \\
\hline & 50 & 0,300 & 83,84 & $\%$ \\
\hline & 60 & 0,250 & 63,54 & $\%$ \\
\hline & 80 & 0,180 & 31,26 & $\%$ \\
\hline & 100 & 0,150 & 18,66 & $\%$ \\
\hline & 200 & 0,075 & 1,60 & $\%$ \\
\hline 3. & \multicolumn{2}{|c|}{ Atterberg Limit } & NON PLASTIS \\
\hline \hline
\end{tabular}

Sumber : Hasil Pengujian Laboratorium 


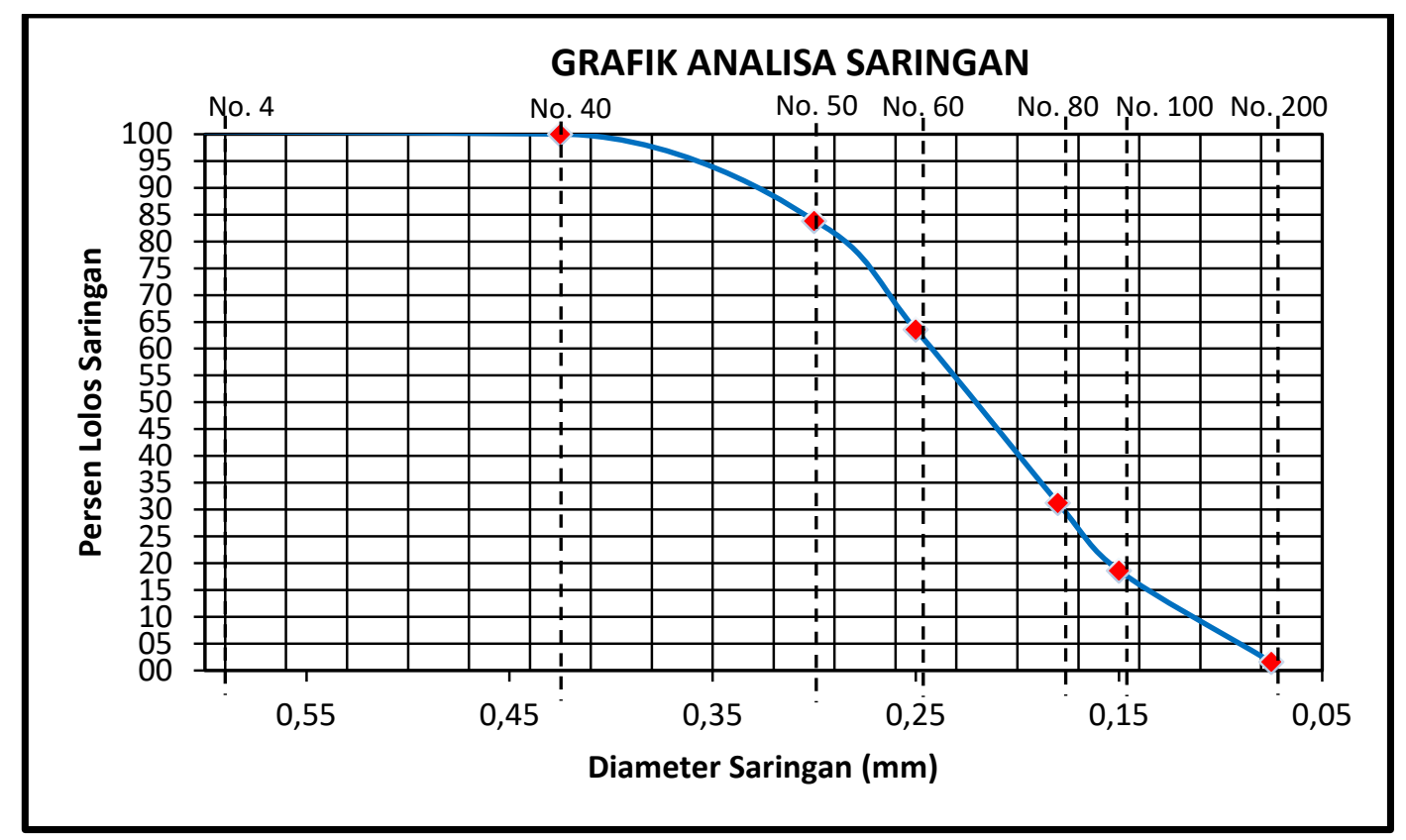

Gambar 2. Grafik pengujian analisa saringan

4.2. Penelitian Sifat Mekanis Tanah

4.2.1. Pengujian Kompaksi ( Proctor Test)

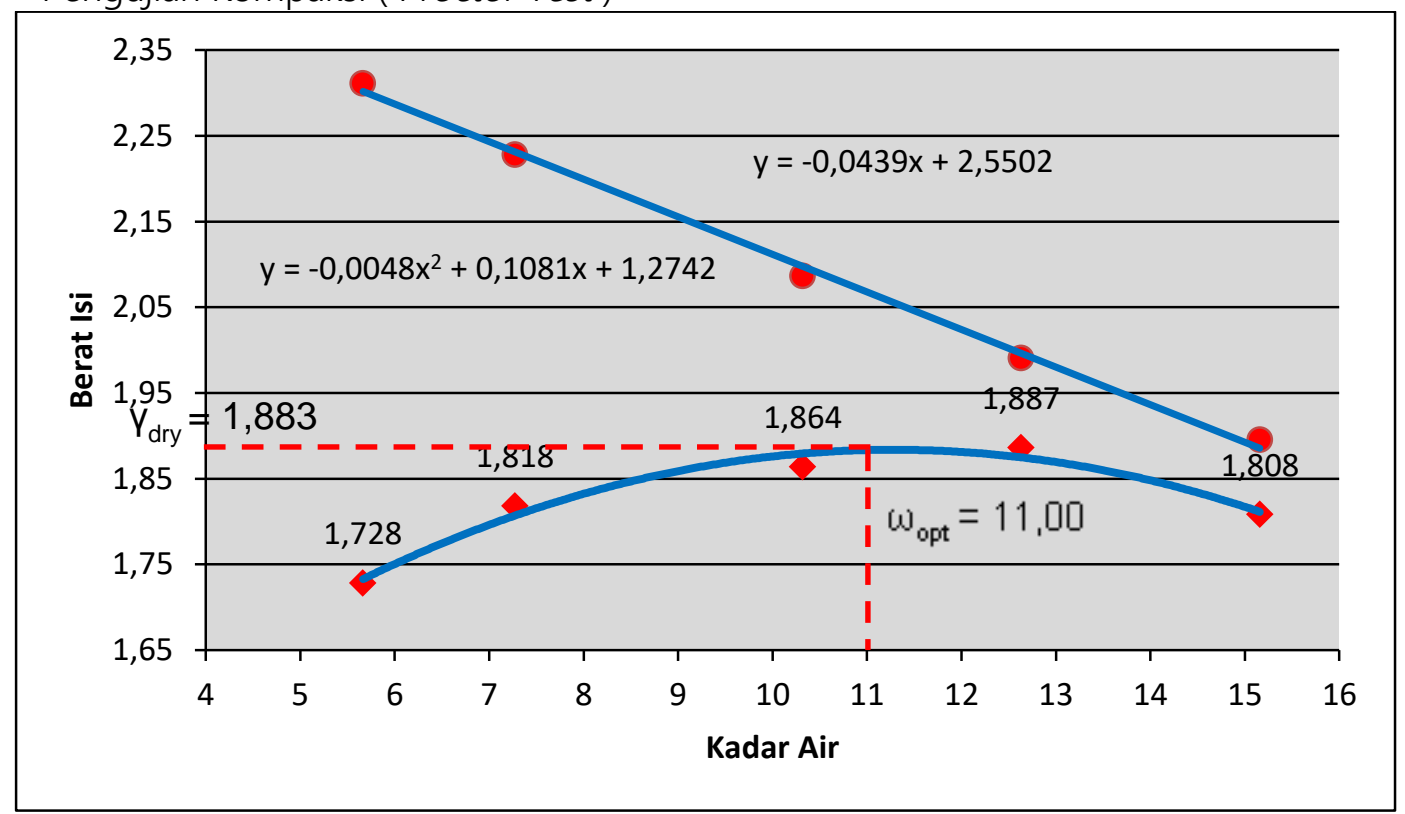

Gambar 3. Grafik pengujian kompaksi 


\subsubsection{Pengujian Permeabilitas}

Tabel 3. Pengujian Permeabilitas

\begin{tabular}{|l|c|c|c|}
\hline No. Test & & 1 & 2 \\
\hline Luas potongan melintang buret $\left(\mathrm{a}=1 / 4 \mathrm{pd}^{2}\right)$ & $\mathrm{cm}^{2}$ & 0,785 & 0,785 \\
\hline Luas potongan melintang sampel $\left(\mathrm{A}=1 / 4 \mathrm{pD}^{2}\right)$ & $\mathrm{cm}^{2}$ & 32,979 & 32,979 \\
\hline Tinggi puncak hidrolik $(\mathrm{h})$ & $\mathrm{cm}$ & 108,7 & 108,7 \\
\hline Panjang sampel $(\mathrm{L})$ & $\mathrm{cm}$ & 10 & 12 \\
\hline Waktu pengujian $(\mathrm{t})$ & $\mathrm{menit}$ & 30 & 30 \\
\hline Temperatur $(\mathrm{T})$ & ${ }^{\circ} \mathrm{C}$ & 28 & 28 \\
\hline Volume air yang terkumpul ( Q ) & $\mathrm{cm}^{3}$ & 84 & 78 \\
\hline Koefisien Permeabilitas ( QL/ hAt ) & $\mathrm{cm} / \mathrm{menit}$ & 0,0078 & 0,0087 \\
\hline Koefisien Permeabilitas Rata-rata & $\mathrm{cm} /$ menit & \multicolumn{3}{|c|}{0,008257} \\
\hline
\end{tabular}

Sumber: Hasil Pengujian Laboratorium

\subsubsection{Pengujian kuat geser}

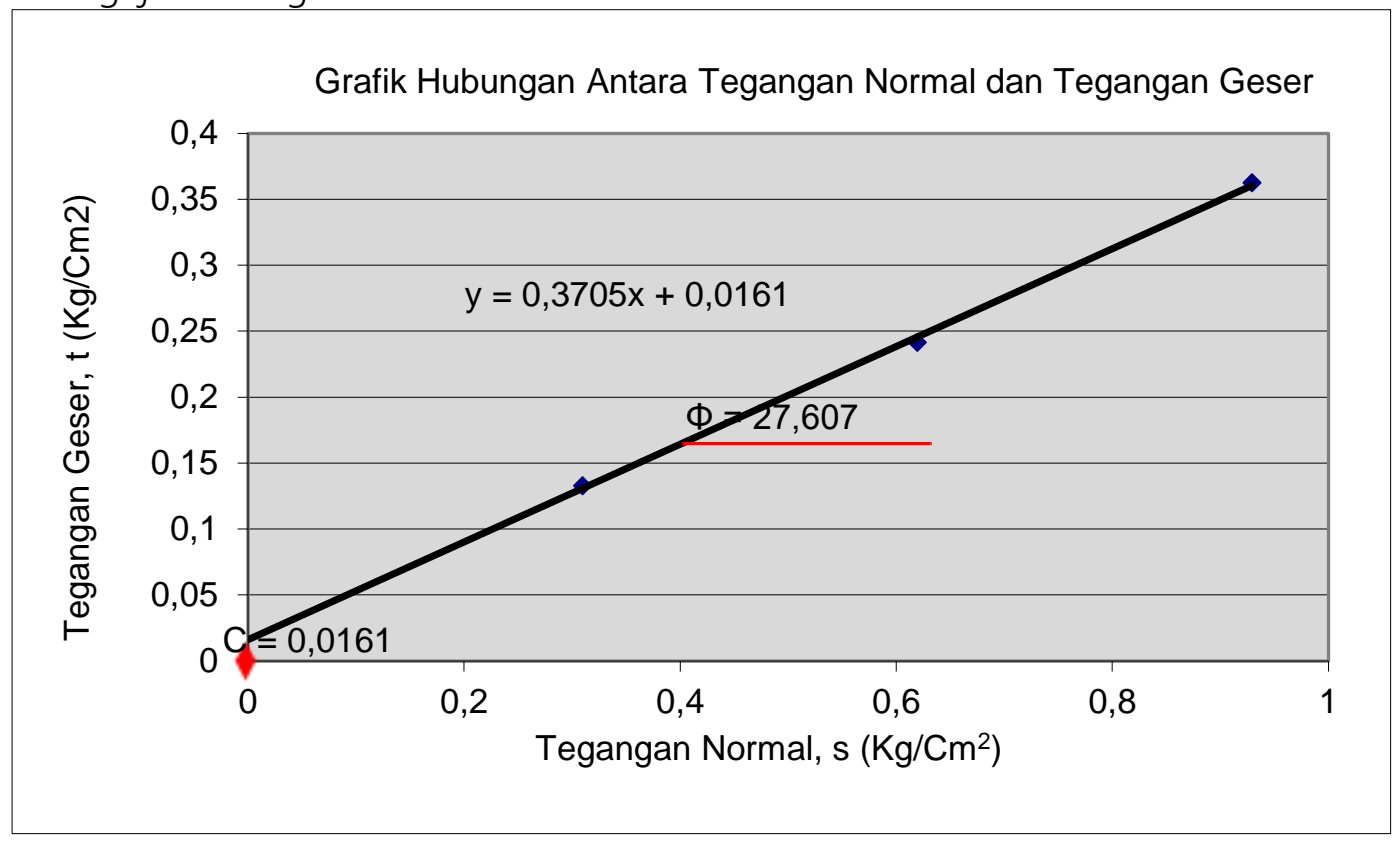

Gambar 4. Grafik pengujian geser langsung

Dengan nilai kuat geser tanah granular :

$$
\tau=0,0161+(0,92964)(\operatorname{tg} 27,607)=0,502 \mathrm{~kg} / \mathrm{cm}^{2}
$$


4.3. Pembahasan

Tabel 4. Hubungan nilai kadar, berat isi variasi kapur

\begin{tabular}{|l|c|c|}
\hline Komposisi Campuran & Kadar air ( \% ) & Berat Isi $\left(\mathrm{gr} / \mathrm{cm}^{3}\right)$ \\
\hline Tanah Asli & 11,00 & 1,88 \\
\hline Tanah asli + Kapur 4\% & 11,16 & 1,83 \\
\hline Tanah asli + Kapur 6\% & 11,32 & 1,79 \\
\hline Tanah asli + Kapur 8\% & 11,58 & 1,75 \\
\hline Tanah asli + Kapur 10\% & 11,88 & 1,73 \\
\hline Tanah asli + Kapur 12\% & 11,92 & 1,69 \\
\hline
\end{tabular}

Sumber: Hasil Pengujian Laboratorium

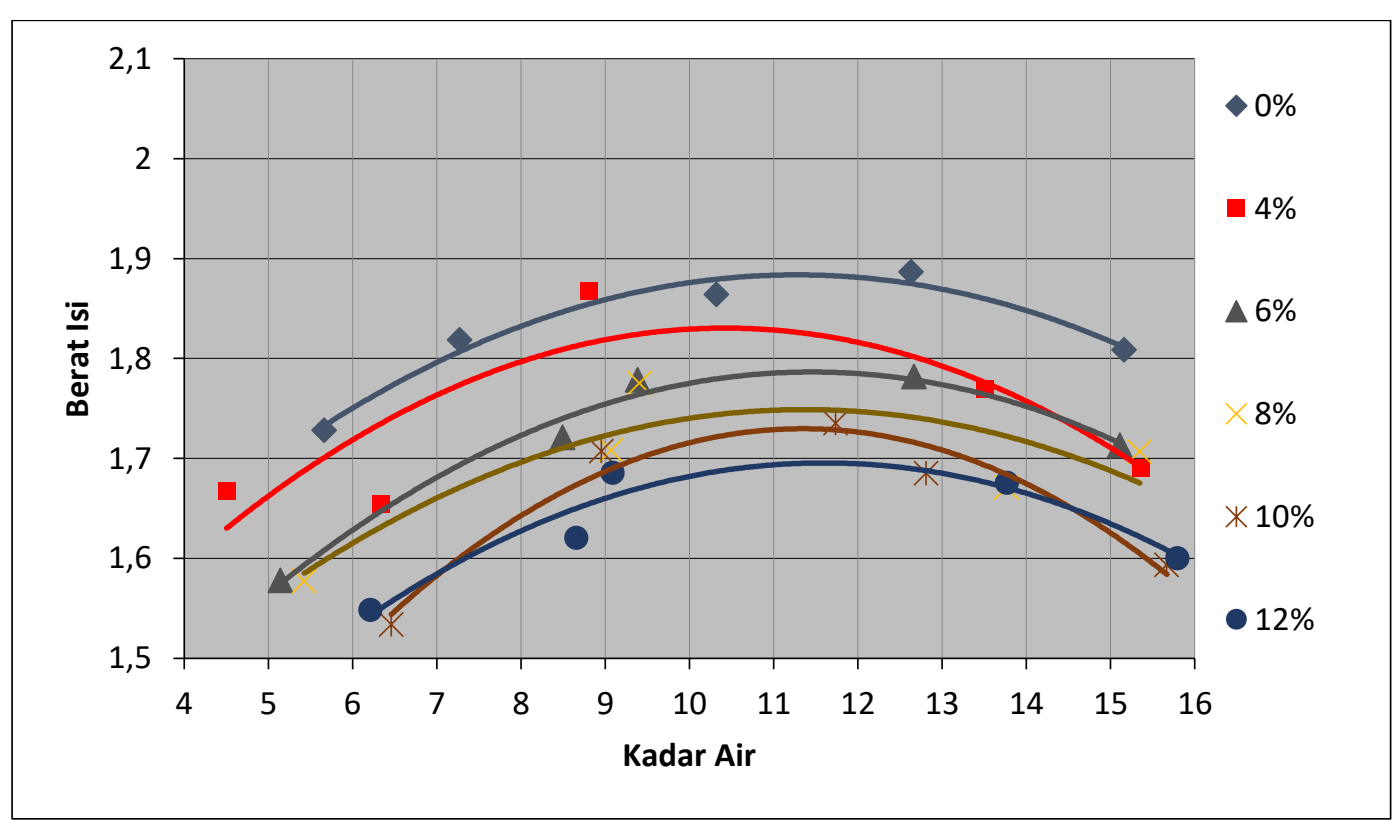

Gambar 5. Grafik hubungan nilai kadar air, berat isi variasi kapur

Hal tersebut disebabkan karena mengecilnya rongga - rongga antara partikel campuran tanah akibat penambahan kapur. Penurunan berat volume kering maksimum, salah satu penyebabnya adalah semakin lepas ( loose ) / tidak padat antar partikel dan terjadinya peningkatan kadari air optimum. 
Tabel 5. Hasil pengujian permeabilitas variasi kapur

\begin{tabular}{|l|c|}
\hline \multicolumn{1}{|c|}{ Komposisi Campuran } & $\begin{array}{c}\text { Koefisien Permeabilitas rata - rata } \\
(\mathrm{cm} / \text { menit })\end{array}$ \\
\hline Tanah Asli & 0,00825 \\
\hline Tanah asli + Kapur 4\% & 0,00694 \\
\hline Tanah asli + Kapur 6\% & 0,00569 \\
\hline Tanah asli + Kapur 8\% & 0,00424 \\
\hline Tanah asli + Kapur 10\% & 0,00321 \\
\hline Tanah asli + Kapur 12\% & 0,00243 \\
\hline
\end{tabular}

Sumber : Hasil Pengujian Laboratorium

Hubungan Nilai k dengan variasi Kapur

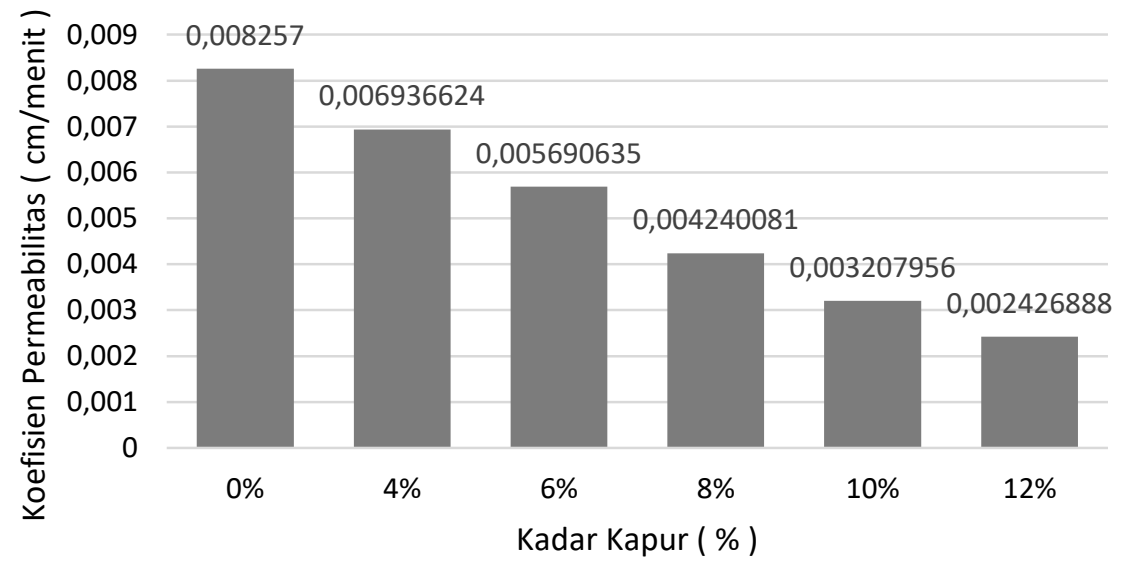

Gambar 6. Grafik hubungan nilai koefisien permeabilitas variasi kadar kapur

Grafik tersebut menunjukkan bahwa nilai k menurun seiring dengan bertambah kadar campuran kapur. Pada campuran kapur $12 \%$, nilai k sebesar $0,00243 \mathrm{~cm} /$ menit. Hal ini menunjukkan bahwa kecepatan rembesan air bergantung pada volume total dari ruangan pori di dalam tanah. Kecilnya ukuran pori tersebut sebagai akibat rekasi kimia yang berupa pengikat kapur oleh partikel pasir. Exchangeable cation yang terdapat pada kapur mengganti lapisan air yang mengelilingi partikel pasir sehingga tanah menjadi lebih buruk. Butiran - butiran tanah tersebut bila dipadatkan akan menghasilkan ukuran pori yang lebih kecil walaupun volumenya berkurang. 
Tabel 6. Hasil pengujian kuat geser variasi kapur

\begin{tabular}{|l|c|c|c|}
\hline \multicolumn{1}{|c|}{ Komposisi Campuran } & $\begin{array}{c}\text { Kohesi } \\
\left.\mathrm{kg} / \mathrm{cm}^{2}\right)\end{array}$ & $\begin{array}{c}\text { Kuat Geser ( } \\
\left.\mathrm{kg} / \mathrm{cm}^{2}\right)\end{array}$ & $\begin{array}{c}\text { Sudut Geser } \\
\left.\text { Dalam ( }{ }^{\circ}\right)\end{array}$ \\
\hline Tanah Asli & 0,016 & 0,502 & 27,607 \\
\hline Tanah asli + Kapur 4\% & 0,081 & 0,454 & 21,873 \\
\hline Tanah asli + Kapur 6\% & 0,093 & 0,369 & 16,602 \\
\hline Tanah asli + Kapur 8\% & 0,101 & 0,359 & 15,562 \\
\hline Tanah asli + Kapur 10\% & 0,105 & 0,320 & 13,050 \\
\hline Tanah asli + Kapur 12\% & 0,113 & 0,305 & 11,537 \\
\hline
\end{tabular}

Sumber : Hasil Pengujian Laboratorium

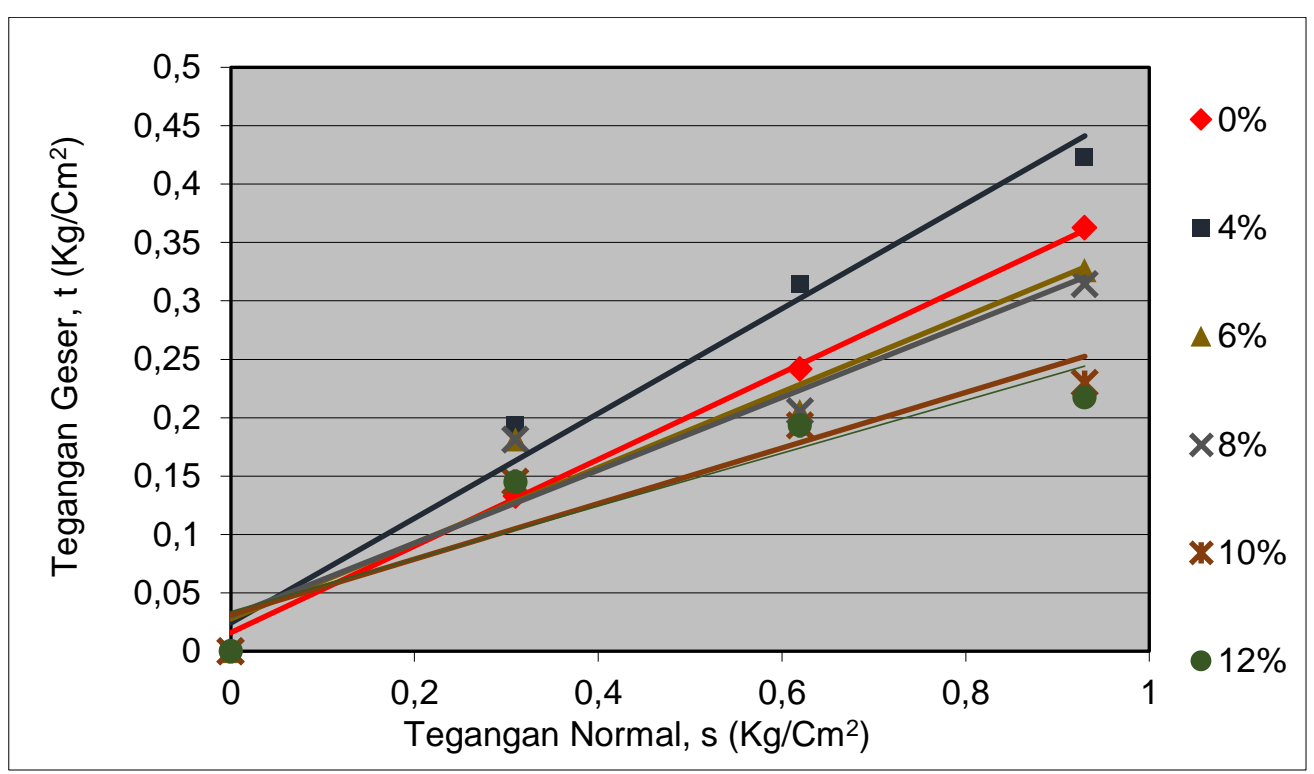

Gambar 7. Hubungan Nilai Sudut Geser Variasi Kadar Kapur

Semakin kuat ikatan antar butir akan menghasilkan nilai kuat geser semakin tinggi dan begitu pula sebaliknya. Dari analisa yang dilakukan sebagaimana diuraikan di atas, dapat disimpulkan bahwa stabilisasi dengan kapur pada tanah berbutir kasar (pasir) ini dapat memperbaiki sifat fisis dan mekanis tanah.

\section{KESIMPULAN DAN SARAN}

5.1. Kesimpulan

Berdasarkan analisis data yang telah didapat dalam penelitian ini maka dapat diambil beberapa kesimpulan sebagai berikut :.

1. Berdasarkan klasifikasi tanah sistem USCS

Tanah pasir Jl. Ahmad Yani Kecamatan Benteng Kepulauan Selayar dikelompokkan ke dalam tanah berbutir kasar yaitu lebih 50\% butiran yang lolos saringan No. 4 ( 4,750 mm ), pasir 
kurang dari 5\% yang lolos saringan No. 200 ( 0,075 mm ). Dengan hasil perhitungan Cu dan $\mathrm{Cc}$ diperoleh $\mathrm{Cu}=2,168, \mathrm{Cc}=1,106$, maka tanah ini dikelompokkan tanah dengan simbol SP - SM yaitu pasir dengan gradasi buruk.

2. Berdasarkan klasifikasi tanah system AASHTO

Tanah pasir ini dikelompokkan ke dalam material granuler yaitu kurang dari 35\% lolos saringan no. 200, dengan simbol klasifikasi kelompok ( A-1; A3; A2 ). Tipe material pada tanah ini adalah pasir halus, dengan penilaian umum sebagai tanah dasar adalah sangat baik sampai baik.

3. Terjadinya peningkatan nilai kohesi ( c ) dan menurunnya sudut geser dalam ( $\phi$ ) pada pengujian Kuat Geser Langsung dengan variasi campuran kapur. Peningkatan maksimum terjadi pada persentase $12 \%$ yaitu $c=0,113 \mathrm{~kg} / \mathrm{cm}^{2}$ dan $\phi=11,537^{\circ}$. Hal ini disebabkan karena kapur memiliki tingkat penyerapan air, sehingga memiliki daya ikat antara partikel. Ikatan antara butiran mampu saling mengunci.

4. Pada pengujian permeabilitas nilai koefisien permeabilitasnya ( $k$ ) menurun seiring bertambahnya variasi campuran kapur. Penurunan maksimum terjadi pada persentase $12 \%$ yaitu $\mathrm{k}=0,00243 \mathrm{~cm} /$ menit. Hal ini disebabkan karena mengecilnya ukuran pori pada tanah pasir yang distabilisasi dengan kapur.

5.2. Saran

1. Hasil dari penelitian ini diharapkan dapat digunakan sebagai bahan pertimbangan apabila ingin mengembangkan penelitian ini.

2. Dapat dipertimbangkan mengenail alternative bahan stabilisasi lain untuk tanah berbutir kasar, khususnya pasir supaya dapat diperoleh perbandingan yang lebih baik guna memperbaiki kondisi tanah pasir tersebut.

DAFTAR PUSTAKA

1. Anonim, 2006, "Pedoman, Penuntun dan Tata Cara Penulisan Tugas Akhir ", JTS FT Universitas " 45 " Makassar.

2. Anonim, 2015, "Penuntun Prakaikum Mekanika Tanah", Jurusan Sipil Fakultas Teknik Universitas Bosowa", Makassar

3. ARBA, 1959. Lime Stabilization and Lime Modification. Amerika

4. Akhmad Irfan, Gatot 2011. Analisis Kekuatan Geser Tanah Pada Berbagai Tekstur Tanah. ( Online ) ( http:www.Google.com diakses pada 19 Januari 2017 )

5. Agus, Lucky. 2006. Karakterisitik Kuat Tarik Tanah Pasir Yang Distabilisasi Dengan Campuran Kapur Dan Abu Sekam Padi. ( Online ) ( http:www.Google.com diakses pada 19 Januari 2017)

6. Agus Setyo. 2011. Karakteristik Kuat Geser Tanah Pasir dengan Campuran Kapur dan Abu Sekam Padi. ( Online ) (http:www.Google.com diakses pada 28 Maret 2017 )

7. Panguriseng, Darwis. 2001. Stabilisasi Tanah. Universitas 45. Makassar.

8. Panguriseng, Darwis. 2001. Mekanika Tanah I dan Gologi Rekayasa. Universitas 45. Makassar.

9. Panguriseng, Darwis. 2001. Mekanika Tanah // dan Mekanika Batuan. Universitas 45. Makassar. 
10. Trissiyana, 2015. Pengaruh Waktu Pemeraman dengan Penambahan Kapur Sebagai Bahan Additive Tanah Lempung Ekspansif Terhadap Nilai CBR Tanah. ( Online ) ( http:www.Google.com diakses pada 28 Maret 2017 ).

11. Yus Yudhyanto, 2013. Analisis Kepadatan Dan Nilai Koefisien Permeabilitas Tanah Lempung Yang Distabilisasi Kapur. ( Online ) ( http:www.Google.com diakses pada 24 juli 2017 ) 